\title{
Military Spending, International Trade and Economic Growth in the Mediterranean Basin
}

\author{
By Gregory T. Papanikos ${ }^{* 1}$
}

In this paper, I argue that a peaceful environment can be created by opening up the trade between the countries of the Mediterranean basin, preferably by bilateral and multilateral agreements like the ones which established the European Union and the Eurozone. Data on military spending, trade and Gross Domestic Product (GDP) of 20 Mediterranean countries are used in a simple descriptive analysis to identify the relation between military spending and international trade, and military spending and economic growth. The descriptive evidence shows that military spending differs considerably between the twenty Mediterranean countries examined in this study. There is a negative relation between international trade and military spending. Tests show that the causality runs from trade to military spending. Military spending does not seem to have an effect on economic growth.

Keywords: Economic growth, International trade, Mediterranean countries, Military spending

\section{Introduction: The Mediterranean Basin}

Written history and abundant archaeological evidence reveals that the Mediterranean sea was the world center of wars and trade for many centuries. It is hard to find a single historical period when this great region of the world was not at war or at conflict. No matter how many pacifying attempts have been made, war and conflicts seem unavoidable. Political, cultural, and religion differences among the countries at the shores of the Mediterranean sea can explain, to a certain extent, the rivalries. Undoubtedly, wars and conflicts are fueled, if not caused, by economic development differences in many of the countries in the basin. Taken this as given, the argument to be made in this paper is that a more peaceful environment can be created by opening up the trade between the countries of the Mediterranean basin, preferably by bilateral and multilateral agreements like the ones which established the European Union and the Eurozone. If more trade and economic integration make wars a second best option and therefore as a result lower the need for military spending, policies to promote trade could contribute to a more peaceful Mediterranean basin, even if this is not the primary objective of promoting international trade.

\footnotetext{
* President, ATINER, Honorary Professor of Economics, University of Stirling, U.K.

${ }^{1}$ This paper was the author's opening speech at the 8th Annual International Conference on Mediterranean Studies, 30-31 March 2015, Athens, Greece.
} 
This paper's analysis is simple, descriptive and selective. Data on military spending, trade (exports plus imports) and growth of Gross Domestic Product (GDP) of 20 Mediterranean countries are used in a simple descriptive analysis to identify the relation between military spending and international trade and military spending and economic growth. This analysis benefits from a selective use of the relevant, and in many cases recent literature on the economic impact of military expenditures. Theoretical, methodological and econometric issues are not discussed and the interested reader should consult the cited papers of this study.

\section{Military Spending in the Mediterranean Countries}

Table 1 gives summary statistics on military expenditures of the 20 Mediterranean countries for which data are available. For 12 countries (60\% of the sample), data exist for the entire period under consideration (26 years). Israel turns out to be the biggest spender with an average expenditure of close to $10 \%$ of GDP for the total period under consideration (1988-2013). Israel's spending was never lower than $5.00 \%$ and it was as high as $18.6 \%$ of GDP.

On the other hand, a number of European countries in the Mediterranean (Spain, Malta and Slovenia) have never spent more than 2.0\% of their GDP in any year under consideration. From the Eurozone countries, Cyprus and Greece have spent the most, $3.7 \%$ and $3.0 \%$ respectively. Croatia has spent a high proportion but the average of the last 15 years is less than $2.0 \%$.

Table 1. Military Spending in the Mediterranean Countries (Average of Military Spending as \% of GDP over the 1988-2013 Period)

\begin{tabular}{|c|l|c|c|c|c|c|}
\hline & Country & Years & Average & St. Dev. & Max & Min \\
\hline 1 & Albania & 25 & 2.227 & 1.486 & 5.888 & 1.228 \\
\hline 2 & Algeria & 26 & 3.132 & 0.886 & 4.951 & 1.231 \\
\hline 3 & Bosnia and Herzegovina & 12 & 1.646 & 0.748 & 3.625 & 1.133 \\
\hline 4 & Croatia & 19 & 3.304 & 2.515 & 9.203 & 1.629 \\
\hline 5 & Cyprus & 26 & 3.689 & 2.071 & 9.129 & 1.793 \\
\hline 6 & Egypt, Arab Rep. & 26 & 3.444 & 1.185 & 6.276 & 1.668 \\
\hline 7 & France & 26 & 2.699 & 0.427 & 3.528 & 2.181 \\
\hline 8 & Greece & 26 & 2.993 & 0.319 & 3.593 & 2.370 \\
\hline 9 & Israel & 26 & 9.67 & 3.371 & 18.598 & 5.630 \\
\hline 10 & Italy & 26 & 1.837 & 0.149 & 2.207 & 1.519 \\
\hline 11 & Lebanon & 25 & 4.908 & 1.359 & 7.980 & 1.187 \\
\hline 12 & Libya & 13 & 2.635 & 1.326 & 5.297 & 0.921 \\
\hline 13 & Malta & 26 & 0.771 & 0.135 & 1.108 & 0.562 \\
\hline 14 & Montenegro & 8 & 1.829 & 0.209 & 2.313 & 1.572 \\
\hline 15 & Morocco & 26 & 3.663 & 0.571 & 5.801 & 2.321 \\
\hline 16 & Slovenia & 19 & 1.389 & 0.146 & 1.610 & 1.095 \\
\hline 17 & Spain & 26 & 1.27 & 0.269 & 1.912 & 0.916 \\
\hline 18 & Syrian Arab Republic & 20 & 6.239 & 1.340 & 9.693 & 4.098 \\
\hline 19 & Tunisia & 26 & 1.695 & 0.308 & 2.315 & 1.262 \\
\hline 20 & Turkey & 26 & 3.218 & 0.690 & 4.143 & 2.218 \\
\hline
\end{tabular}

Source: World Bank; the data are averages of the 1988-2013 period or for years in which data are available (http://www.worldbank.org/). 
The differences between the countries are huge. Table 2 groups the countries into European/non-European and Eurozone/non-Eurozone. Even the difference in mean spending between European and Eurozone countries is statistically significant at $8.0 \%$ level. On average, non-Europeans spend almost double on military than the European countries, $4.5 \%$ and $2.3 \%$ respectively. Between the non-Eurozone and Eurozone countries, the difference is $1.76 \%$ of GDP.

Table 2. Summary Statistics of Military Spending in the Mediterranean Countries, 1988-2013 (\% of GDP)

\begin{tabular}{|l|c|c|c|c|c|}
\hline & Total & European & Non-European & Eurozone & Non-Eurozone \\
\hline Mean & 3.20 & 2.29 & 4.49 & 2.12 & 3.88 \\
\hline Median & 2.48 & 1.90 & 3.81 & 1.89 & 3.40 \\
\hline Maximum & 18.60 & 9.20 & 18.60 & 9.13 & 18.60 \\
\hline Minimum & 0.56 & 0.56 & 0.92 & 0.56 & 0.92 \\
\hline St. Dev. & 2.40 & 1.41 & 2.89 & 1.28 & 2.68 \\
\hline Skewness & 2.34 & 2.05 & 1.87 & 2.09 & 2.05 \\
\hline Kurtosis & 11.06 & 8.88 & 7.79 & 9.96 & 8.95 \\
\hline
\end{tabular}

Source: World Bank (http://www.worldbank.org/) \& Author's Estimations.

Note: All mean differences are statistically significant with at least 0.01 probability.

The high values of skewness and kurtosis in the series provides evidence regarding the existence of cross-country differences. The high value of kurtosis in the Eurozone countries can be explained by the higher spending of Greece and Cyprus.

\section{Trade and Military Spending}

The basic assumption made here is that trade brings peace and therefore decreases the need for more military expenditures. Figure 1 provides supportive descriptive evidence of this hypothesis for the Mediterranean basin countries. Military expenditures are measured as percentages of GDP and are averaged for each country over the $1988-2013$ period, pending the availability of data as is shown in Table 1 above. Trade is measured as the percentage of the sum of exports and imports to GDP averaged over the years in which data are available. Figure 1 shows that trade has been increasing throughout the period even though in some years sharp decreases were observed, particularly during the recent economic crisis, which started in 2008. Trade (exports plus imports) increased from less than $70 \%$ of GDP in the 1990s to more than $80 \%$ in the 2010s. During the same period, military expenditures have been decreasing from $4.5 \%$ of GDP in the late 1980 s to less than $2.5 \%$ in the $2010 \mathrm{~s}$. 
Figure 1. Military Spending and Trade in the Mediterranean Countries, 19882013

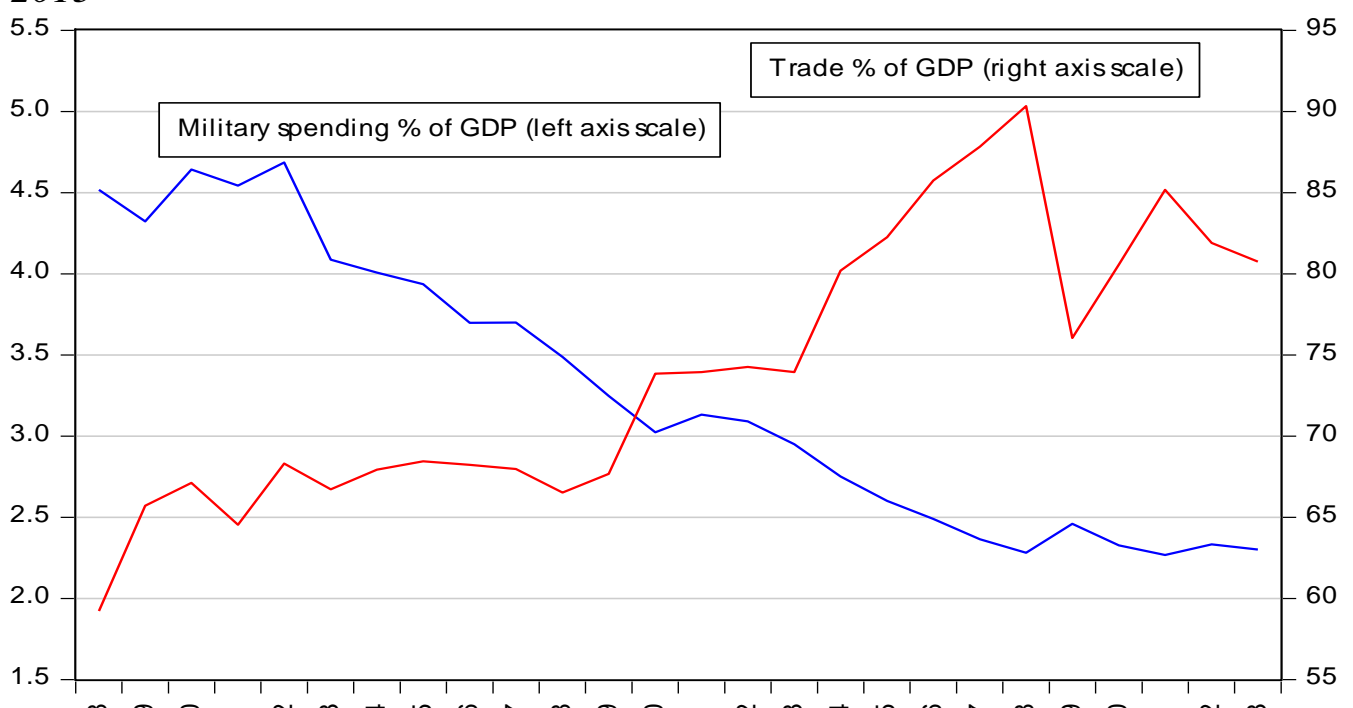

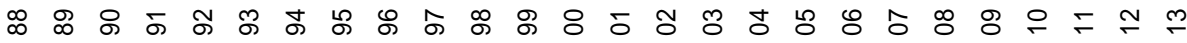
Source: Author's Estimations.

Thus, the relation appears to be negative. Figure 2 shows just that in a scatter diagram of military spending and trade, both are measured as percentages of GDP. The simple regression line has a negative slope, and is relatively steep. Military spending of around $2.5 \%$ of GDP is associated with trade shares of GDP from about $75 \%$ to up to $90 \%$. On the other side, trade shares of GDP of less than $75 \%$ are associated with military spending of more than $3.0 \%$ of GDP.

Figure 2. Military Spending and Trade in the Mediterranean Countries (Country Averages of the 1988-2013 Years)

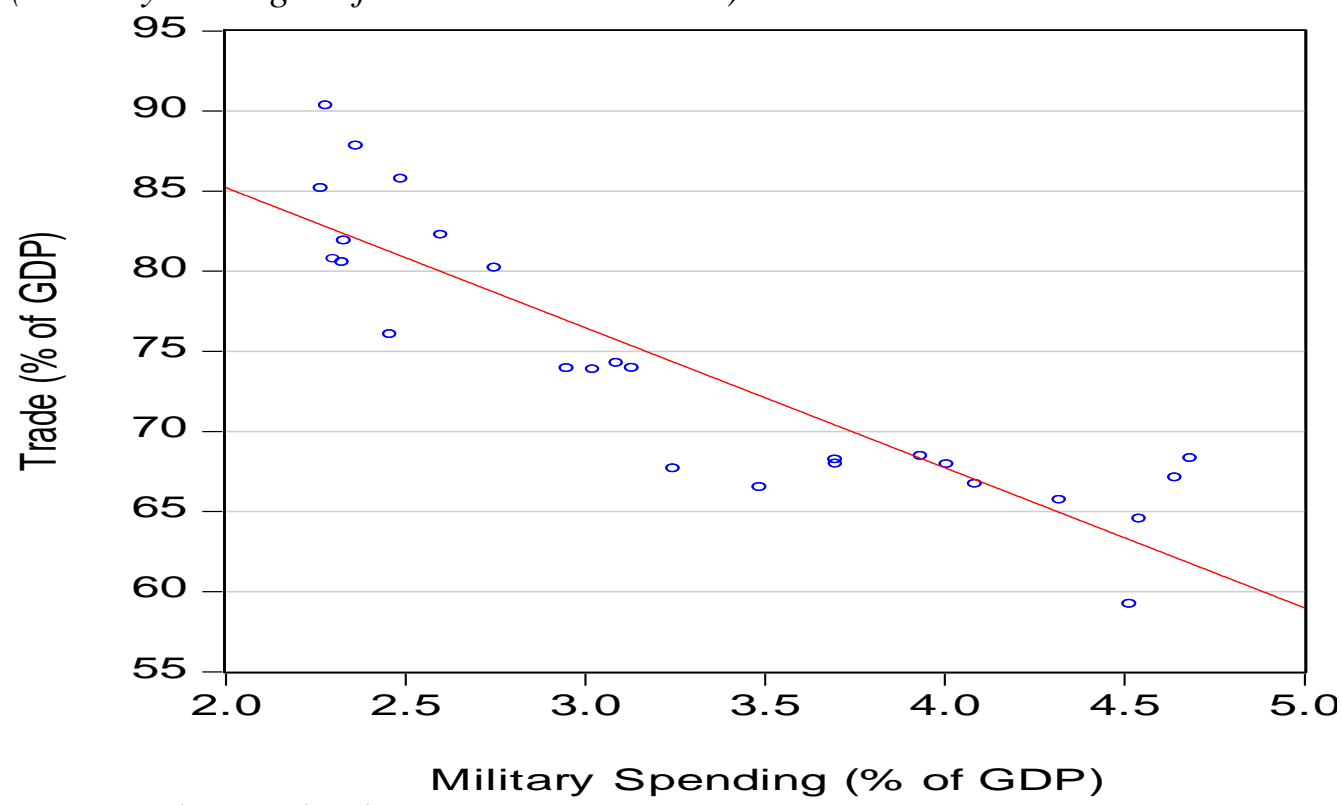

Source: Author's Estimations. 
A logarithmic regression of the two variables shows that the elasticity of military spending as a percentage of GDP with respect to the trade percentage of GDP is -0.4 . Thus, an increase in trade shares by $10 \%$ (for example from $75 \%$ to $82.5 \%$ of GDP), will decrease military spending from $3.2 \%$ of GDP to about $2.0 \%$ of GDP. These are large numbers and have significant effects on economic and social welfare. Military expenditures are public expenditures, and saved funds from military can be used to improve health and education, and reduce poverty.

Correlation does not imply causality. It might be the case that it is not trade that causes a reduction in military spending but rather military spending that decreases trade. The estimated relationship between trade and military spending should be tested for reverse causality bias. Table 3 shows the results of panel Granger causality tests. The hypothesis that military spending does not Granger cause international trade in the Mediterranean countries cannot be rejected. On the other hand, the hypothesis that trade does not Granger cause military spending is rejected. It appears that (Granger) causality runs one-way, from trade to military spending. Thus, one may conclude that the hypothesis that international trade has a negative impact on military expenditures as a percentage of GDP, cannot be rejected.

Table 3. Panel Granger Causality Tests

\begin{tabular}{|l|c|c|c|c|}
\hline Null Hypothesis & Sample & Obs & F-Statistic & Prob. \\
\hline MILITARY does not Granger Cause TRADE & Total & 425 & 2.25 & 0.13 \\
\hline TRADE does not Granger Cause MILITARY & Total & 425 & 3.49 & 0.06 \\
\hline MILITARY does not Granger Cause TRADE & European & 247 & 1.71 & 0.19 \\
\hline TRADE does not Granger Cause MILITARY & European & 247 & 4.70 & 0.03 \\
\hline MILITARY does not Granger Cause TRADE & Non-European & 178 & 1.28 & 0.26 \\
\hline TRADE does not Granger Cause MILITARY & Non-European & 178 & 0.74 & 0.39 \\
\hline MILITARY does not Granger Cause TRADE & Eurozone & 163 & 2.20 & 0.14 \\
\hline TRADE does not Granger Cause MILITARY & Eurozone & 163 & 1.00 & 0.32 \\
\hline MILITARY does not Granger Cause TRADE & Non-Eurozone & 262 & 0.86 & 0.35 \\
\hline TRADE does not Granger Cause MILITARY & Non-Eurozone & 262 & 4.11 & 0.04 \\
\hline
\end{tabular}

Source: Author's Estimations.

Recently, Seitz et al. (2015) have developed an empirical model to account for this negative and casual relation from international trade to military expenditures. They discussed two reasons why this is the case. First, an increase in trade between two countries or between countries in one region, increases the dependency between the countries making less probable a conflict. Second, more peaceful relations make defense spending a waste of resources which can be re-directed to other types of spending. The authors claim that there is a snowball effect. Other countries follow in reducing military, spending resulting in a worldwide increase in welfare. 


\section{Economic Growth and Military Spending}

Many studies have examined the impact of military spending on economic growth. Dunne et al. (2005) review some of the theoretical and empirical issues that relate military expenditures to economic growth. Most of the mainstream economic growth literature finds that these two variables are not related. On the other hand, the economics of military spending literature find significant impact of defense spending on economic growth. Most of them use the FederRam model (Ram 1995) which Dunne et al. (2005) consider inappropriate because it suffers from theoretical and empirical problems. They examine the mainstream economic growth models such as the Solow and Barro models, which they consider as more promising. They suggest that these models can be used to account for non-linear impacts of military spending on economic growth: positive when the security threat is high and negative when it is low.

The key issues are how military expenditures affect economic growth through aggregate demand, investment, productivity etc. For example, Caruso and Francesco (2012) examined military expenditures in Italy using time series data for the 1988-2008 period. They found that there is a negative relation between military spending and long run productivity. They suggest that if nonmilitary expenditures are increased at the cost of military spending, productivity will increase as well as Italy's economic growth.

Figure 3 graphs the rate of growth of GDP of the Mediterranean countries against their military expenditures as a share of GDP. The scatter diagram shows that there is no apparent relation between defense spending and economic growth in the total sample of the 20 countries of the Mediterranean countries. For the subsample of the European (non-European) and the Eurozone (non-Eurozone) countries, it appears that there is a slight positive (negative) relation between military spending and economic growth (not shown in the diagram). This confirms the meta-analysis of the empirical evidence of growth and military spending reported by Alptekin and Levine (2012). They concluded that economic growth is positively related to military spending in the developed countries. 
Figure 3. Military Spending and Economic Growth in the Mediterranean Countries (Averages of 1988-2013 years)

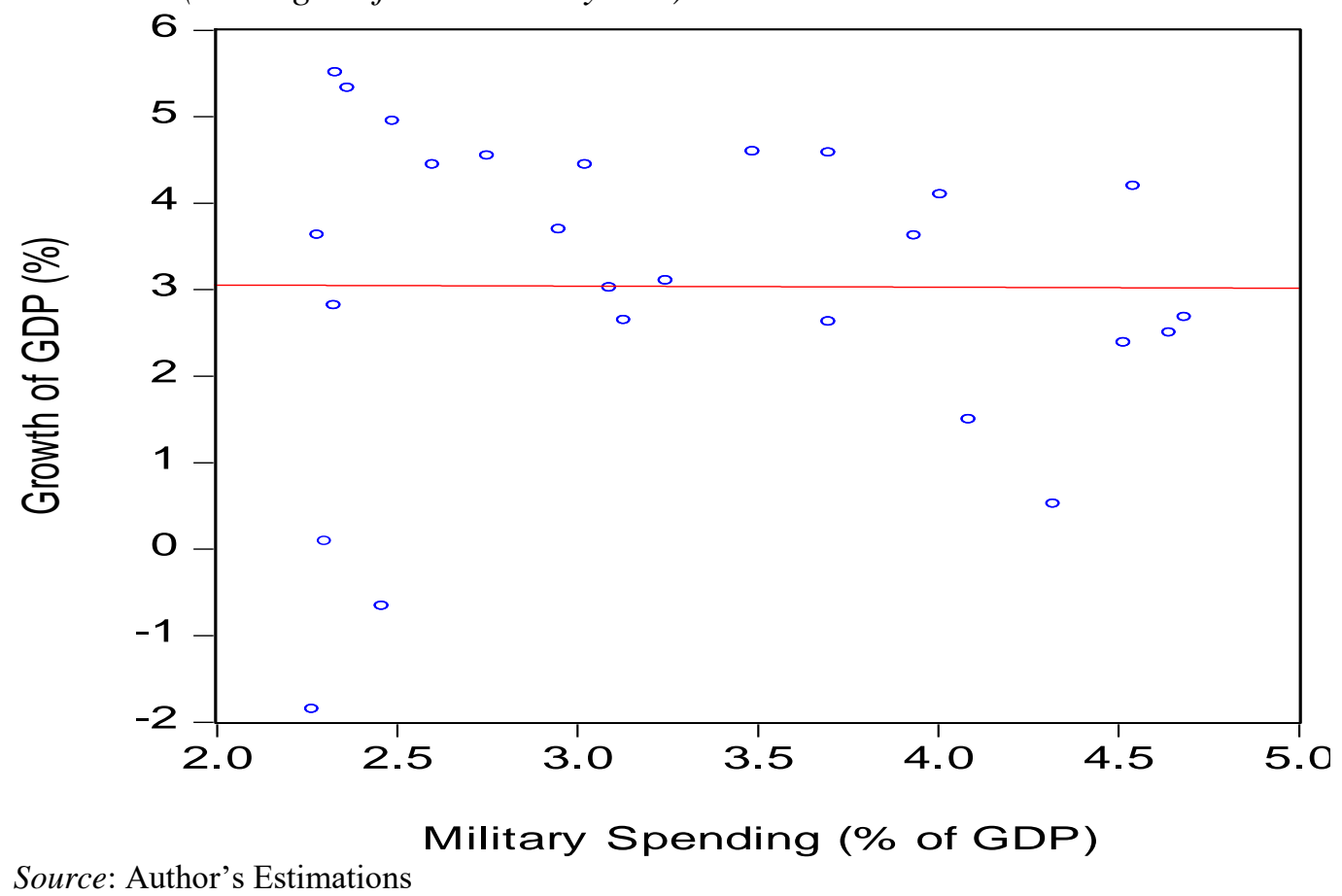

Another strand of this literature relates corruption and non-democratic political regimes to military spending, see among others Gupta et al. (2001) and Islam (2015). This literature finds that in less developed countries military spending may be negatively related to economic growth. This supports the descriptive evidence of negative relation between economic growth and military spending in the non-European countries of the Mediterranean basin.

The Granger causality tests (not reported) cannot provide conclusive evidence for all cases of the cause-effect impact of military spending (economic growth) on economic growth (military spending).

\section{Conclusions}

This paper provided descriptive evidence on the relationship between military spending and international trade and between military spending and economic growth. A number of conclusions can be drawn from this analysis. First, military spending differs considerably between the twenty Mediterranean countries examined in this study. Differences exist between the European and the non-European Mediterranean countries as well as between the Eurozone and non-Eurozone Mediterranean countries. Second, the simple descriptive evidence shows that there is a negative relation between international trade increase and military spending, and tests show that the causality most probably runs from trade to military spending. Third, military spending does not seem to have an effect on economic growth. For the subsample of the European (non- 
European) and the Eurozone (non-Eurozone) countries, a weak positive (negative) relation exists between military spending and economic growth (not shown in the diagram). The causality tests cannot provide conclusive evidence on the direction of the effects.

\section{References}

Alptekin A, Levine P (2012) Military expenditure and economic growth: A metaanalysis. European Journal of Political Economy 28(4): 636-650.

Caruso R, Francesco A (2012) Country survey: Military expenditure and its impact on productivity in Italy, 1988-2008. Defence and Peace Economics 23(5): 471-484.

Dunne JP, Smith RP, Willenbockel D (2005) Models of military expenditure and growth: A critical review. Defence and Peace Economics 16(6): 449-461.

Gupta S, de Mello L, Sharan R (2001) Corruption and military spending. European Journal of Political Economy 17(4): 749-777.

Islam MN (2015) Economic growth, repression, and state expenditure in nondemocratic regimes. European Journal of Political Economy 37(March): 68-85.

Ram R (1995) Defense expenditure and economic growth. In. Hartley K, Sandler T (ed.) Handbook of Defense Economics. Amsterdam: Elsevier, 251-273.

Seitz M, Tarasov A, Zakharenko R (2015). Trade costs, conflicts, and defense spending. Journal of International Economics 95(2): 305-318. 